\title{
PHYSIOLOGICAL CORRELATES OF CYCLING PERFORMANCE IN AMATEUR MOUNTAIN BIKERS
}

\author{
Donvina Vaitkevičiūtė, Kazys Milašius \\ Lithuanian University of Educational Sciences, Vilnius, Lithuania
}

\begin{abstract}
Research background and hypothesis. Aerobic fitness of high-performance mountain bikers explains about $40 \%$ of variance in performance. This suggests that other factors such as anaerobic power and capacity as well as technical abilities need to be considered in the physiological assessment (Impellizzeri et al., 2005 a). We found a lot studies investigating track and road cyclists, but there are no studies concerning the relationship between physiological tests and cycling performance in Lithuanian mountain bikers.

The aim of this study was to investigate the physiological correlates of cycling performance in amateur mountain bikers.

Research methods. Fifteen Lithuanian mountain bikers participated in the study. The 10-second test was performed to estimate special alactic anaerobic power output, whereas ae 30 -second Wingate test was performed to estimate composite alactic anaerobic glycolytic power output. For the evaluation of the aerobic capacity, a progressive incremental laboratory cycling test to exhaustion was performed.

Research results. We found a significant negative correlation between cycling performance and alactic anaerobic relative peak power output $(\mathrm{r}=-0.534, \mathrm{p}<0.05)$ and lactate concentration after the progressive incremental cycling test to exhaustion $(\mathrm{r}=-0.625, \mathrm{p}<0.05)$. However, we did not find a significant correlation between cycling performance and $\mathrm{VO}_{2} \max (\mathrm{r}=-0.024, \mathrm{p}>0.05)$ and composite alactic anaerobic glycolytic power output $(\mathrm{r}=-0.269, \mathrm{p}>0.05)$.

Discussion and conclusions. Our findings suggest that alactic anaerobic power output and active glycolysis play a very important role in off-road cycling performance. This is essential because of the fast starting phase of the race and steep climbs.
\end{abstract}

Keywords: mountain bike, cycling, performance, power output, maximal oxygen uptake.

\section{INTRODUCTION}

M ountain biking (off-road cycling) is becoming increasingly popular in Lithuania. The most popular mountain biking events are cross-country (XC) and marathon, often referred to as cross-country marathon (XCM). Both events are a mass-start endurance competition. Cross country involves completing several laps of an off-road circuit, typically the course is between $6 \mathrm{~km}$ and $9 \mathrm{~km}$ long and winning time is about 120-135 minutes for men and 105-120 minutes for women (Impellizeri, Marcora, 2007). Marathons cover at least 40 kilometers of trial. Mountain biking events include repeated descents and hill climbs on gravel roads and wilderness trails.
Mountain biking is a physically demanding sport (Baron, 2001). The duration of these events suggest that high aerobic power and the ability to sustain high intensity exercises for a prolonged period is required and the fast starting phase, as well as fighting against gravity during the steep climbs, (up to $500 \mathrm{~W}$ ) suggest that anaerobic metabolism plays a significant role (Impellizeri et al., 2002). $\mathrm{VO}_{2} \max$ is considered to be a standard indicator of the integrated function of cardiovascular, respiratory and muscular systems during exercise and an important determinant of endurance performance (Bassett, Howley, 2000). T. Cramp et al. (2004) reported $\mathrm{VO}_{2}$ max values 
in amateur mountain bikers at $60.0 \mathrm{ml} / \mathrm{min} / \mathrm{kg}$, whereas elite mountain bikers have $\mathrm{VO}_{2}$ max value at $78.3 \mathrm{ml} / \mathrm{min} / \mathrm{kg}$ (Lee et al., 2002). Aerobic fitness of high-performance mountain bikers explains about $40 \%$ of variance in performance. This suggests that other factors as anaerobic power as well as capacity and technical abilities need to be considered in the physiological assessment of these athletes (Impellizzeri et al., 2005 b).

During mountain biking competitions, different terrain conditions require mountain bikers to have a high degree of technical ability to control and stabilize the bicycle. Riders might increase their speed downhill and can gain advantage or decrease the time lost in other parts of the course (Wang, Hull, 1997).

We found a lot studies investigating the track and road cyclists, but there are very few studies on Lithuanian mountain biker's physiological profile (Vaitkevičūte, Milašius, 2011) and none on the relationship between physiological tests and cycling performance.

The aim of this study was to investigate the physiological correlates of cycling performance in amateur mountain bikers.

\section{RESEARCH METHODS}

Participants. Fifteen Lithuanian mountain bikers (19-29 years old) who participated in mountain biking marathons were tested during the competitive phase of their season. The marathon was a mass start event and took part in Vilnius (19 06 2011), with the course consisting of a 26-kilometer lap and all participants completing two laps.

Anthropometry. These indices of physical development were measured: body mass, muscle and fat body mass, BMI, hand grip strength and vital lung capacity (Table 1).

Laboratory tests. Muscle power in different zones of energy production was studied. The 10 -second test was performed to estimate the special alactic anaerobic power output, whereas the 30 -second Wingate test was performed to estimate composite alactic anaerobic glycolytic power output using a Monark 894E veloergometer. For the evaluation of aerobic capacity, a progressive incremental laboratory cycling test to exhaustion was performed using Oxycon Mobile, a telemetric breath-by-breath system. During this test, pulmonary ventilation (VE), heart rate (HR), oxygen uptake $\left(\mathrm{VO}_{2}\right)$ and power output $(\mathrm{W})$ was continuously registered at the anaerobic threshold and intermittent critical power intensity (PCi).

Statistical analysis. The data were analysed using descriptive statistics and are presented as the mean $( \pm$ ) standard deviation (s), coefficient of variation (V\%) and range. We used a Pearson's correlation coefficient (r) to calculate the correlation between cycling performance and physiological

\begin{tabular}{|l|c|c|c|c|c|}
\hline \multicolumn{1}{|c|}{ Indices } & Mean & $\begin{array}{c}\text { Standard } \\
\text { deviation } \\
\text { (S) }\end{array}$ & $\begin{array}{c}\text { Coefficient of } \\
\text { Variation } \\
\text { (V\%) }\end{array}$ & Min & Max \\
\hline Height, cm & 181.90 & 5.45 & 3.00 & 173.00 & 192.00 \\
\hline Body mass, kg & 71.61 & 7.21 & 10.07 & 58.30 & 85.50 \\
\hline BMI & 21.62 & 1.67 & 7.72 & 18.90 & 24.45 \\
\hline Muscle mass, kg & 37.95 & 4.40 & 11.59 & 28.30 & 45.50 \\
\hline Fat mass, kg & 7.45 & 2.38 & 31.95 & 4.20 & 12.30 \\
\hline Hand grip strength, $\mathrm{kg}$ & 63.07 & 5.11 & 8.10 & 50.00 & 71.00 \\
\hline VLC, 1 & 5.81 & 0.64 & 11.02 & 4.40 & 6.70 \\
\hline
\end{tabular}

Table 1. Anthropometric and physiometric characteristics of amateur mountain bikers

\begin{tabular}{|l|c|c|c|c|c|}
\hline \multicolumn{1}{|c|}{ Indices } & Mean & $\begin{array}{c}\text { Standard } \\
\text { deviation } \\
\text { (S) }\end{array}$ & $\begin{array}{c}\text { Coefficient of } \\
\text { Variation } \\
\text { (V\%) }\end{array}$ & Min & Max \\
\hline $10 \mathrm{~s} \mathrm{max,} \mathrm{W/kg}$ & 21.10 & 1.92 & 9.08 & 18.47 & 24.43 \\
\hline $10 \mathrm{~s}$ mean, W/kg & 14.00 & 1.04 & 7.41 & 12.61 & 16.20 \\
\hline $30 \mathrm{~s}$ mean, W/kg & 9.40 & 0.66 & 7.01 & 8.38 & 10.37 \\
\hline Race time, s & 7837.51 & 572.66 & 7.31 & 6903.35 & 9004.30 \\
\hline
\end{tabular}

Table 2. Relative anaerobic power output and race time values 
capacities ( $\mathrm{r}=0.514, \mathrm{p}<0.05 ; \mathrm{r}=0.641, \mathrm{p}<0.01)$. For performing statistical analyses we used Microsoft Office Excel 2007 and SPSS Statistics 17.0.

\section{RESEARCH RESULTS}

Table 2 shows that the calculated coefficients of variations for the $10 \mathrm{~s}$ test, $30 \mathrm{~s}$ - Wingate test and cycling performance remained low $(<10 \%$ coefficient of variation). We found that the alactic anaerobic relative peak power output was $21.10 \mathrm{~W} / \mathrm{kg}$, the alactic anaerobic relative power output was $14.00 \mathrm{~W} / \mathrm{kg}$, the composite alactic anaerobic glycolytic power output was $9.40 \mathrm{~W} / \mathrm{kg}$ and the average race time was $7837.51 \mathrm{~s}$.

The data of aerobic capacity (Table 3) had different coefficients of variation. The V\% of HR at intermittent critical power (PCi) intensity and anaerobic threshold was low, $<10 \%$ just as $\mathrm{VO}_{2} \max$ at PCi. All other data (except La, which had $<30 \%$ coefficient of variation) had medium coefficient of variation $(<20 \%)$. The $\mathrm{VO}_{2} \max$ at the $\mathrm{PCi}$ was $58.51(48.18-73.56) \mathrm{ml} / \mathrm{min} / \mathrm{kg}$ and at the anaerobic threshold it was $43.84(34.90-55.20) \mathrm{ml} / \mathrm{min} / \mathrm{kg}$. Respectively the power output was $411.33 \mathrm{~W}$ and $271.33 \mathrm{~W}$. The blood lactate concentration after the progressive incremental laboratory cycling test to exhaustion was $12.40 \mathrm{mmol} / 1(8.10-16.20 \mathrm{mmol} / \mathrm{l})$.
We found a significant negative correlation between cycling performance and alactic anaerobic relative peak power output $(\mathrm{r}=-0.534, \mathrm{p}<0.05)$ and lactate concentration after the progressive incremental cycling test to exhaustion $(r=-0.625$, $\mathrm{p}<0.05$ ) (Table 4). Also alactic anaerobic relative power output had a significant negative correlation with $\mathrm{VO}_{2}$ max at anaerobic threshold $(\mathrm{r}=-0.516$, $\mathrm{p}<0.05)$. However, we did not find a significant correlation between cycling performance and $\mathrm{VO}_{2} \max (\mathrm{r}=-0.024, \mathrm{p}>0.05)$ and composite alactic anaerobic glycolytic power output $(r=-0.269, p>0.05)$. Composite alactic anaerobic glycolytic power output had no significant positive correlation with lactate concentration $(r=0.255$, $\mathrm{p}>0.05$ ), either.

Oxygen pulse (OP) had strong significant positive correlation with power output at intermittent critical power (PCi) intensity and anaerobic threshold $(\mathrm{r}=0.721, \mathrm{p}<0.01 ; \mathrm{r}=$ $0.682, \mathrm{p}<0.01) . \mathrm{VO}_{2} \max$ at intermittent critical power (PCi) intensity was significantly positively correlated with $\mathrm{VO}_{2} \max$ at anaerobic threshold $(r=0.761, p<0.01)$.

\section{DISCUSSION}

We believe this is the first time physiological correlates of cycling performance are reported in amateur mountain bikers. A few studies investigated correlations between physiological

Table 3. Responses to progressive incremental laboratory cycling test to exhaustion at anaerobic threshold and PCi

\begin{tabular}{|c|c|c|c|c|c|c|}
\hline \multicolumn{2}{|r|}{ Indices } & Mean & $\begin{array}{c}\text { Standard } \\
\text { deviation (S) }\end{array}$ & $\begin{array}{c}\text { Coefficient of } \\
\text { Variation (V\%) }\end{array}$ & Min & Max \\
\hline \multirow{7}{*}{ 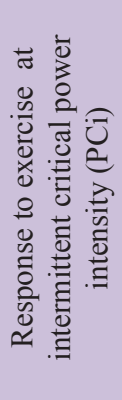 } & $\mathrm{VE}, 1 / \mathrm{min}$ & 159.80 & 22.71 & 14.21 & 122.00 & 203.00 \\
\hline & HR, bpm & 187.07 & 10.09 & 5.39 & 163.00 & 200.00 \\
\hline & $\mathrm{VO}_{2} \max , 1 / \min$ & 4.19 & 0.56 & 13.48 & 3.27 & 5.48 \\
\hline & $\mathrm{VO}_{2} \max , \mathrm{ml} / \mathrm{min} / \mathrm{kg}$ & 58.51 & 5.80 & 9.91 & 48.18 & 73.56 \\
\hline & $\mathrm{O}_{2}$ pulse, $\mathrm{O}_{2} / \mathrm{HR}$ & 22.52 & 3.84 & 17.06 & 16.35 & 30.61 \\
\hline & W & 411.33 & 45.65 & 11.10 & 330.00 & 510.00 \\
\hline & $\mathrm{La}, \mathrm{mmol} / \mathrm{l}$ & 12.40 & 3.00 & 24.16 & 8.10 & 16.20 \\
\hline \multirow{6}{*}{ 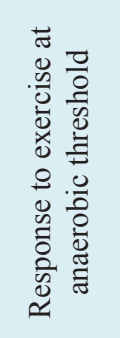 } & $\mathrm{VE}, 1 / \mathrm{min}$ & 75.33 & 11.16 & 14.81 & 55.00 & 95.00 \\
\hline & $\mathrm{HR}, \mathrm{bpm}$ & 166.73 & 9.73 & 5.83 & 153.00 & 185.00 \\
\hline & $\mathrm{VO}_{2}, 1 / \mathrm{min}$ & 3.14 & 0.52 & 16.65 & 2.03 & 3.91 \\
\hline & $\mathrm{VO}_{2}, \mathrm{ml} / \mathrm{min} / \mathrm{kg}$ & 43.84 & 5.95 & 13.58 & 34.90 & 55.20 \\
\hline & $\mathrm{O}_{2}$ pulse, $\mathrm{O}_{2} / \mathrm{HR}$ & 18.92 & 3.67 & 19.40 & 11.47 & 25.56 \\
\hline & W & 271.33 & 45.65 & 16.82 & 170.00 & 330.00 \\
\hline
\end{tabular}




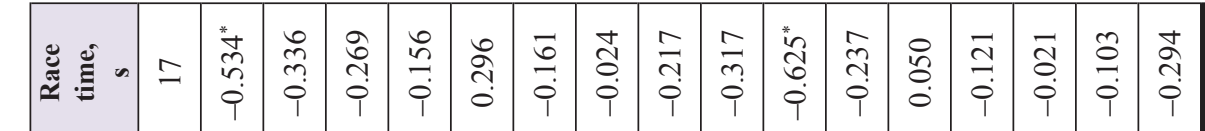

\begin{tabular}{|c|c|c|c|c|c|c|c|c|c|c|c|c|c|c|c|}
\hline$\stackrel{\circ}{\circ}$ & $\frac{n}{i}$ & $\frac{\text { I }}{\stackrel{9}{9}}$ & $\begin{array}{c}\mathcal{J} \\
\mathfrak{d} \\
i\end{array}$ & $\begin{array}{l}\text { oे } \\
\text { के }\end{array}$ & 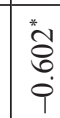 & $\begin{array}{l}\frac{*}{2} \\
\frac{2}{0} \\
0\end{array}$ & $\begin{array}{l}\vec{I} \\
\stackrel{0}{0}\end{array}$ & $\begin{array}{l}\frac{*}{0} \\
\stackrel{0}{\infty} \\
0 \\
0\end{array}$ & 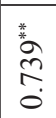 & $\stackrel{m}{0}$ & $\begin{array}{l}0 \\
\stackrel{0}{0} \\
n \\
0\end{array}$ & $\begin{array}{l}\stackrel{n}{f} \\
\stackrel{q}{9}\end{array}$ & $\begin{array}{l}\text { ڤे } \\
\text { ठे }\end{array}$ & $\begin{array}{l}\stackrel{*}{\circ} \\
\stackrel{\circ}{0} \\
0\end{array}$ & \begin{tabular}{l}
$*$ \\
\multirow{2}{*}{} \\
$\alpha$ \\
$\sigma$ \\
$\delta$
\end{tabular} \\
\hline
\end{tabular}

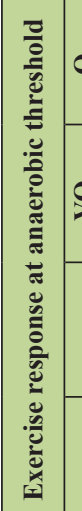

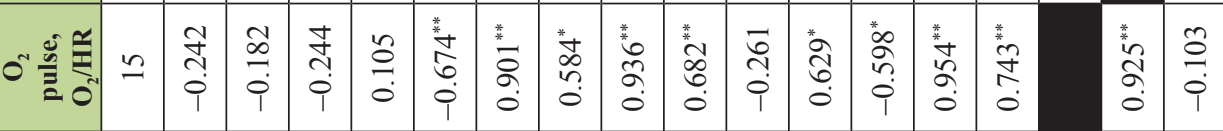

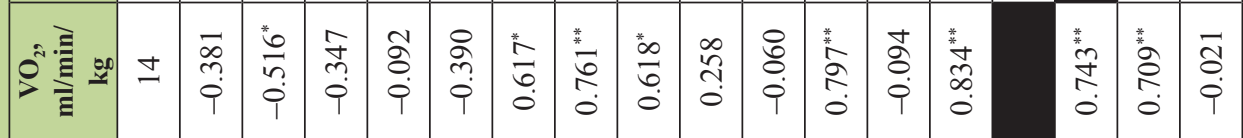

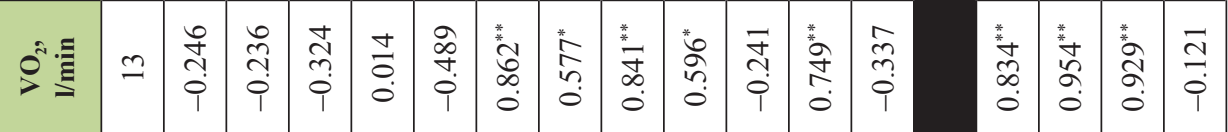

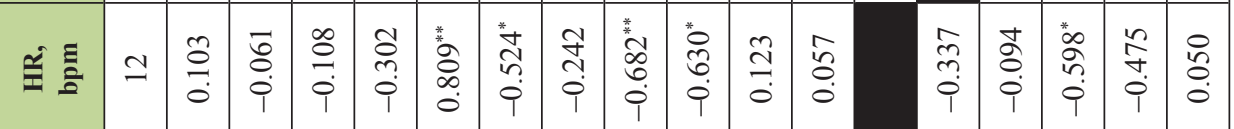

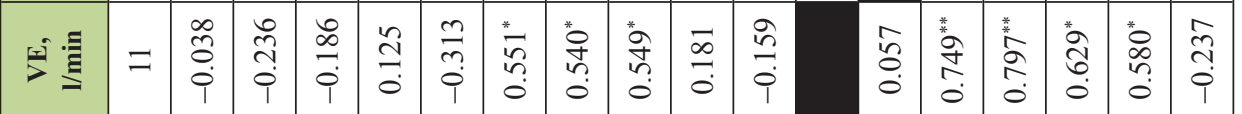

手言

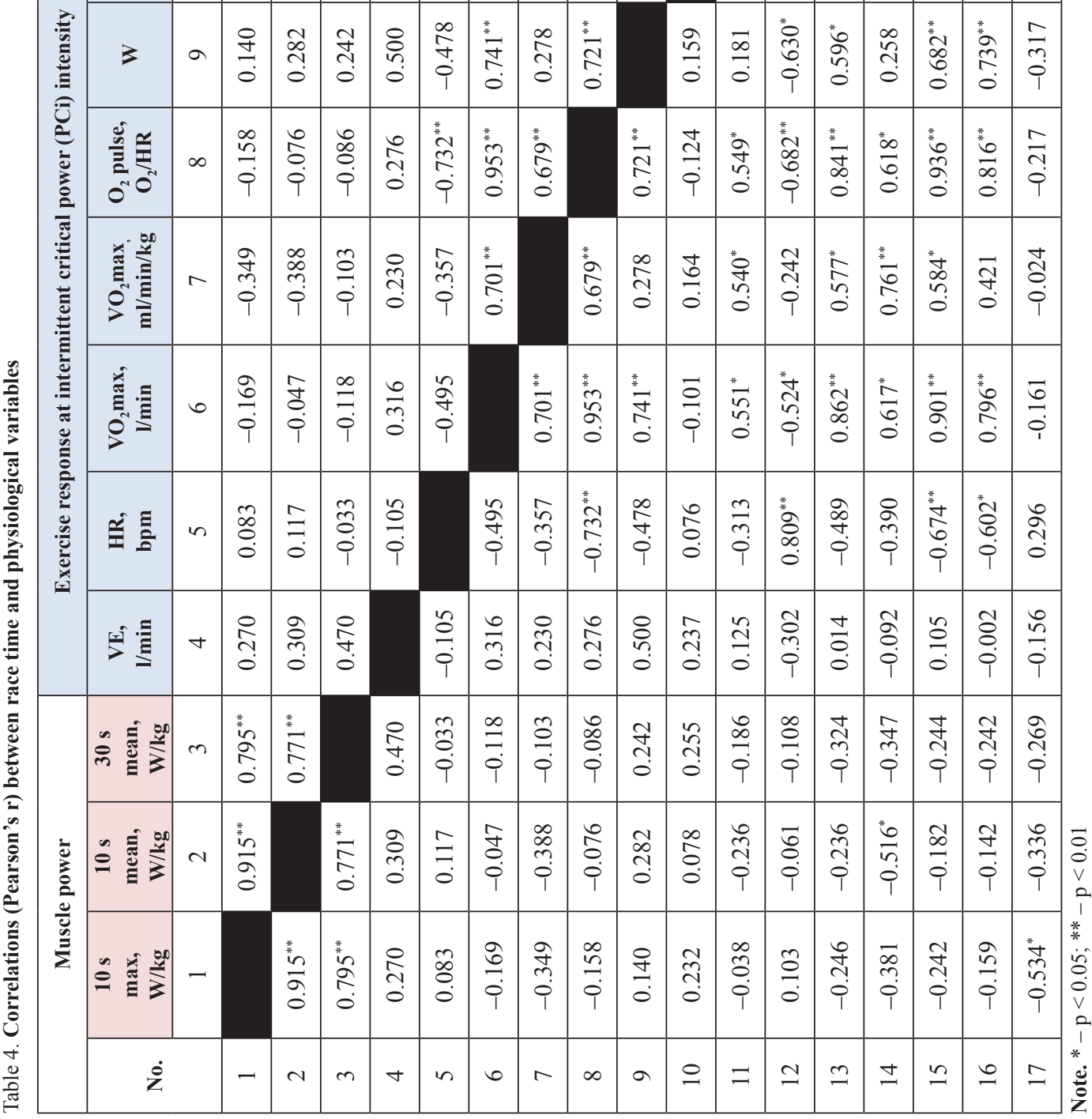


variables and performance in elite off-road cyclist (Impellizzeri et al., 2005 a, b; Costa, De-Oliveira, 2008; Costa et al., 2011). Cross country marathon (XCM) is a mass-start competition. Starting position is defined according to UCI (International Cycling Union) points during international events or national points system during national events. This system lets the best athletes start the race at the front of the group, so they are not being slowed down by lower performing bikers. Different starting positions have influence on race time and its correlation to the physiological variables.

Up to now, there have been no studies investigating the alactic anaerobic peak power relationship to cross country marathon (XCM) performance. As we know, only one study reports about the correlation between Wingate test and cross country (XC) performance (Costa, De-Oliveira, 2008). During Wingate test both the phosphagen and glycolytic systems are fully activated (Boobis et al., 1982), and during a $10 \mathrm{~s}$ test the phosphagen system plays the most important role (Gaitanos et al., 1993). V. P. Costa, F. R. De-Oliveira (2008) and we found no significant correlation between Wingate test variables and cycling performance. Still we discovered that alactic anaerobic relative peak power is significantly correlated to cycling performance.

F. M. Impellizeri et al. (2005 a) reported that $\mathrm{VO}_{2} \mathrm{max}$, power output, anaerobic threshold expressed both in absolute terms and relative to body mass were significantly correlated to race time. Thirteen national and international offroad cyclists (under 23 in the UCI classification) participated there. Later, F. M. Impellizeri et al. (2005 b) studied fifteen elite off-road cyclists and the results were different. This group was more homogeneous, but they found no significant correlation between $\mathrm{VO}_{2} \max$ and power output. They concluded that the physiological predictor of performance in a heterogeneous group of athletes cannot be applied to elite athletes who are characterized by a more homogeneous performance ability.
Aerobic fitness of high-performance mountain bikers explains about $40 \%$ of the variance in performance. This suggests that other factors such as anaerobic power and capacity and technical abilities need to be considered in the physiological assessment of these athletes (Impellizzeri et al., 2005 b). Our results are similar, we found no significant correlation between aerobic fitness and cycling performance, except for lactate concentration after a progressive incremental laboratory cycling test to exhaustion. V. P. Costa et al. (2008) notified that the intermittent nature of cross country could promote larger demand and utilization of anaerobic metabolism during training and/or races. B. Stapelfeldt et al. (2004) quantified the intensity during cross country races and indicated that $42 \%$ of the race time was above anaerobic threshold. This explains that active glycolysis plays a very important role in off-road cycling performance.

Our further studies should investigate the influence of physiological parameters and the technical ability in the cycling performance of homogeneous mountain bikers' group.

\section{CONCLUSIONS AND PERSPECTIVES}

Significant negative correlation between alactic anaerobic relative peak power output and race time $(\mathrm{p}<0.05)$ proves that alactic anaerobic power output is crucial for amateur mountain bikers because of the quick starting phase and steep climbs during race time.

Significant negative correlation between lactate concentration after a progressive incremental cycling test to exhaustion and race time $(\mathrm{p}<0.05)$ suggests that glycolysis plays a very important role in off-road cycling performance, which requires high anaerobic power and capacity of amateur mountain bikers.

This group of amateur mountain bikers should be characterized by heterogeneous performance level.

\section{REFERENCES}

Baron, R. (2001). Aerobic and anaerobic power characteristics of off-road cyclists. Medicine and Science in Sports and Exercise, 33, 1387-1393.

Bassett, D., Howley, E. (2000). Limiting factors for maximum oxygen uptake and determinants of endurance performance. Medicine and Science in Sports and Exercise, 32, 70-84.
Boobis, L. H., Williams, C., Wooton, S. A. (1982). Human muscle metabolism during brief maximal exercise. Journal of Physiology, 338, 21-22.

Costa, V. P., Carminatti, L. J., Nakamura, F. Y., DeOliveira, F. R. (2008). Morpho-physiological similarities between road cyclists and mountain bikers. Italian Journal of Sport Sciences, 1, 1-11. 
Costa, V. P., De-Oliveira, F. R. (2008). Physiological variables to predict performance in cross-country mountain bike races. Journal of Exercise Physiology Online, 11, 14-24.

Costa, V. P., Pertence, L. C., Matos, D. G. et al. (2011). Physiological correlates of $10 \mathrm{~km}$ up-hill cycling performance in competitive cyclists. Journal of Exercise Physiology Online, 14, 26-33.

Cramp, T., Broad, E., Martin, D., Meyer, B. J. (2004). Effects of pre-exercise carbohydrate ingestion on mountain bike performance. Medicine and Science in Sports and Exercise, 36, 1602-1609.

Gaitanos, G., Williams, C., Boobis, L., Brooks, S. (1993). Human muscle metabolism during intermittent maximal exercise. Journal of Applied Physiology, 75, $712-719$.

Impellizzeri, F. M., Marcora, S. M., Rampinini, E. et al. (2005 a). Correlations between physiological variables and performance in high-performance cross-country off-road cyclists. British Journal of Sports Medicine, 39, $747-751$

Impellizzeri, F. M., Marcora, S. M. (2007). The physiology of mountain biking. Sports Medicine, 37, $59-71$.
Impellizzeri, F. M., Rampinini, E., Sassi, A. et al. (2005 b). Physiological correlations to off-road cycling performance. Journal of Sports Sciences, 23, 41-47.

Impellizzeri, F. M., Sassi, A., Rodriguez-Alonso, M. et al. (2002). Exercise intensity during off-road cycling competitions. Medicine and Science in Sports and Exercise, 34, 1808-1813.

Lee, H., Martin, D. T., Anson, J. M. et al. (2002). Physiological characteristics of successful mountain bikers and professional road cyclists. Journal of Sports Science, 20, 1001-1008.

Stapelfeldt, B., Schwirtz, A., Schumacher, Y., Hillebrecht, M. (2004). Workload demands in mountain bike racing. International Journal of Sports Medicine, 25, 294-300.

Union Cycliste Internationale (UCI) [2012 01 12]. Internet link: < http://www.uci.ch>

Vaitkevičiūtè, D., Milašius, K. (2011). Lietuvos kalnų ir plento dviratininku fizinių ir funkciniu galiu charakteristika. Sporto mokslas, 66 (4), 26-31.

Wang, E. L., Hull, M. L. (1997). A dynamic system model of an off-road cyclist. Journal of Biomechanical Engineering, 119, 248-253.

\title{
MĖGĖJŲ KALNŲ DVIRATININKUূ FIZIOLOGINIUU RODIKLIŲ IR VARŽYBŲ REZULTATO KORELIACINIAI RYŠIAI
}

\author{
Donvina Vaitkevičiūtė, Kazys Milašius \\ Lietuvos edukologijos universitetas, Vilnius, Lietuva
}

\section{SANTRAUKA}

Tyrimo pagrindimas ir hipotezė. Didelio meistriškumo kalnų dviratininkų aerobinè ištvermé varžybų rezultatą lemia tik $40 \%$. Tai rodo, kad tokie veiksniai kaip anaerobinis pajègumas ir ištvermé, techniniai gebejjimai turi būti vertinami atliekant šiu sportininkų fiziologinius tyrimus (Impellizzeri et al., 2005 a). Nors Lietuvos plento ir treko dviratininku klausimais moksliniu publikaciju yra paskelbta nemažai, Lietuvos kalnų dviratininkų fiziologiniu rodiklių ryšiu su varžybų rezultatu moksliniu tyrimų duomenų literatūros šaltiniuose neaptikome.

Tikslas - ištirti mėgèjų kalnų dviratininkų fiziologinių rodiklių ryšius su varžybų rezultatu.

Metodai. Tirta 15 Lietuvos kalnų dviratininkų. Specialiajam anaerobiniam alaktatiniam pajègmui nustatyti buvo taikomas $10 \mathrm{~s}$ trukmès didžiausiu pastangų testas, o mišriam anaerobiniam alaktatiniam-glikolitiniam pajègumui Vingeito $30 \mathrm{~s}$ trukmès didžiausių pastangu testas. Aerobinis pajègumas nustatytas atliekant nuosekliai didinamo krūvio testą veloergometru.

Rezultatai. Nustatyti statistiškai patikimi atvirkštiniai koreliaciniai ryšiai tarp varžybų rezultato ir santykinio didžiausiojo anaerobinio alaktatinio pajègumo $(\mathrm{r}=-0,534 ; \mathrm{p}<0,05)$ bei laktato koncentracijos po nuosekliai didinamo krūvio testo $(\mathrm{r}=-0,625 ; \mathrm{p}<0,05)$. Visgi neaptikome statistiškai patikimo ryšio tarp varžybu rezultato ir $\mathrm{VO}_{2} \max (\mathrm{r}=-0,210 ; \mathrm{p}>0,05)$ bei mišraus anaerobinio alaktatinio-glikolitinio pajëgumo $(\mathrm{r}=-0,269 ; \mathrm{p}>0,05)$.

Aptarimas ir išvados. Tyrimo duomenys leidžia teigti, kad santykinis anaerobinis alaktatinis pajègumas ir aktyvi glikolizè yra būtini kalnų dviračių sporte, kuriam būdinga greito starto fazè ir stačios i̇kalnès varžybų metu.

Raktažodžiai: kalnų dviračių sportas, varžybų rezultatas, pajėgumas, didžiausiasis deguonies suvartojimas.

Gauta 2012 m. gegužès 8 d.

Received on May 8, 2012

Priimta 2012 m. birželio 8 d.

Accepted on June 8, 2012
Corresponding author Donvina Vaitkevičiūtè

Lithuanian University of Educational Sciences

Studentu str. 39, LT - 08106 Vilnius

Lithuania

Tel +370 52734858

E-mail v.donvina@gmail.com 